\title{
INHERITANCE OF HIGH TEMPERATURE TOLERANCE AND SOME RELATED TRAITS IN RICE
}

\author{
Abdel-Hafez ${ }^{1}$, A.G.; A.A. AbdAllah ${ }^{2}$; I.S. El Degwy ${ }^{1}$ and M. I. \\ Ghazy $^{2}$
}

1) Agron. Dept., Faculty Agric., Kafr El-Sheikh University, Egypt.

2) 2) RRTC, Sakha Agric. Res. Station, ARC, Egypt

E-mail: aagahafez2011@agr.kfs.edu.eg

\begin{abstract}
A study was carried out at the Agronomy Department, Faculty of Agriculture, Kafr El-Sheikh University and the Rice Research and Training Center, Field Crop Research Institute, during 2013, 2014 and 2015 seasons to study the inheritance of heat stress tolerance and some traits in rice crosses. The six populations; $\mathrm{P}_{1}, \mathrm{P}_{2}, \mathrm{~F}_{1}, \mathrm{~F}_{2}, \mathrm{BC}_{1}$ and $\mathrm{BC}_{2}$ of each of the three studied crosses were evaluated in the New Valley research field under heat stresses using randomized complete block design (RCBD) with three replications. The results indicated the presence of non-allelic interaction for all studied traits in all crosses. The gene action of the studied traits indicated that additive, dominance and epistemic genetic components was important for the expression of the traits studied. The results showed considerable amount of dominance effect for days to $50 \%$ heading, plant height, total stigma length, anther length, 100-grain weight and grain yield/ plant indicating that selection for these traits should be postponed to the later generations until homozygosity is achieved. Also, the relative importance of additive $\times$ dominance effects varied within traits and crosses under heat conditions. Among the epistatic components, the dominance $\times$ dominance was greater in magnitudes than additive $\times$ additive and additive $\times$ dominance in most of the studied traits. Positive heterotic effects relative to the mid-parent and betterparent were found for most of the studied traits under both conditions.
\end{abstract}

Keywords: Rice, Heat stress, Six populations, Gene action, Heterosis, Potence ratio

\section{INTRODUCTION}

Among the abiotic stresses, extreme temperatures affect severely the growth and productivity of rice as well as the other cereal crops. High temperature stress during the vegetative and reproductive growth phases caused greater and almost equal reduction in biomass and grain yield (Peng et al. 2004). Among yield components, the number of panicles/ plant and grains/ panicle showed greater sensitivity to high temperature stress. To increase the yield potential and in order to reduce the yield gap, improving the varietal adaptability and quality improvement are needed Zou et al. (2011). High temperature is often 
accompanied with low water supply, so the primary aim of rice breeding program must be to develop promising varieties tolerating both types of stresses (Tester and Bacic 2005). Temperature higher than the optimum induced floret sterility and therefor decreased rice yield in some genotypes, also spikelet sterility was increased at temperature higher than $35^{\circ} \mathrm{C}$ (AbdAllah et al. 2010). The present investigation aimed to study the inheritance of heat stress tolerance and some of its related traits and the resulted influence on hybrid vigor in three rice crosses.

\section{MATERIALS AND METHODS}

This study was carried out at the Agronomy Department, Faculty of Agriculture, Kafrelsheikh University and the Rice Research and Training Center (RRTC), Sakha, Kafr EL-Sheikh, Field Crop Research Institute, Egypt, during 2013, 2014 and 2015 seasons. The field experiments was carried out at New Valley Agricultural Research Station, New Valley Governorate, Egypt. Names, pedigree, origin, type and characteristics of these genotypes are presented in Table (1).

Table (1): Origin, pedigree, type and some remarks of the studied varieties

\begin{tabular}{|l|c|c|c|c|}
\hline \multicolumn{1}{|c|}{ Varieties } & Pedigree & Origin & Type & $\begin{array}{c}\text { Drought and heat } \\
\text { reaction }\end{array}$ \\
\hline \hline Sakha 105 & (GZ 5581-46-3/ GZ 4316-7-1-1) & Egypt & Japonica & Sensitive \\
\hline Sakha 101 & (Giza 176/ Milyang 79) & Egypt & Japonica & Sensitive \\
\hline Sakha 102 & (GZ 4096-7-1/ Giza 177) & Egypt & Japonica & Sensitive \\
\hline WAB 880-1-32-1-2-P1-HB & (WAB 56-50/ CG14//WAB56-50) & $\begin{array}{c}\text { Africa Rice Center } \\
\text { (WARDA) }\end{array}$ & Indica & Tolerant \\
\hline IRAT 170 & (IRAT 13/ Palawan) & Ivory Coast & Indica & Tolerant \\
\hline Moroberekan & (IR 8-24-6- (M307 H5) & $\begin{array}{c}\text { Republic of Guinean } \\
\text { (West Africa) }\end{array}$ & $\begin{array}{c}\text { Tropical } \\
\text { Japonica }\end{array}$ & Tolerant \\
\hline
\end{tabular}

Six rice genotypes were used as parents and recurrent parents to produce $F_{1}, F_{2}, B c_{1}$ and $B c_{2}$ in Table (2).

Table (2): The six populations of the three studied crosses

\begin{tabular}{|c|c|c|c|}
\hline \multirow{2}{*}{ Generation } & \multicolumn{3}{|c|}{ Entries } \\
\hline & Cross I & Cross II & Cross III \\
\hline $\begin{array}{c}\mathbf{P}_{1} \\
\mathbf{P}_{2} \\
\mathbf{F}_{1} \\
\mathbf{B C}_{1} \\
\mathbf{B C}_{2} \\
\mathbf{F}_{2}\end{array}$ & $\begin{array}{c}\text { Saskha } 105 \\
\text { WAB } 880-1-32-1-2-P 1-H B \\
\text { Sakha 105 x WAB } 880- \\
\text { Sakha } 105 \text { x WAB } 880-/ \text { Saskha } \\
105 \\
\text { Sakha } 105 \text { x WAB } 880-/ \text { WAB } \\
880- \\
\text { Sakha } 105 \text { x WAB } 880-\text { selfed }\end{array}$ & $\begin{array}{c}\text { Saskha } 102 \\
\text { IRAT } 170 \\
\text { Sakha } 102 \times \text { IRAT } 170 \\
\text { Sakha } 102 \text { x IRAT 170/ } \\
\text { Saskha } 102 \\
\text { Sakha } 102 \times \text { IRAT 170/ } \\
\text { IRAT 170 } \\
\text { Sakha } 102 \times \text { IRAT } 170 \\
\text { selfed }\end{array}$ & $\begin{array}{c}\text { Saskha } 101 \\
\text { Moroberekan } \\
\text { Sakha } 101 \text { x Moroberekan } \\
\text { Sakha } 101 \text { x Moroberekan/ } \\
\text { Saskha } 101 \\
\text { Sakha } 101 \text { x Moroberekan/ } \\
\text { Moroberekan } \\
\text { Sakha } 101 \text { x Moroberekan } \\
\text { selfed }\end{array}$ \\
\hline
\end{tabular}


The six populations of; $\mathrm{P}_{1}, \mathrm{P}_{2}, \mathrm{~F}_{1}, \mathrm{~F}_{2}, \mathrm{BC}_{1}$ and $\mathrm{BC}_{2}$ of each of the three crosses were transplanted in randomized complete block design (R.C.B.D) with three replications. Each plot consists of five rows, five meters long with $20 \mathrm{~cm}$ between rows and plants allowing a total of 25 plant $/ \mathrm{m}^{2}$. All, the cultural practices of growing rice by transplanting method were practiced. Splitting nitrogen fertilizer $(69 \mathrm{~kg}$ $\mathrm{N} / \mathrm{Fed}$ ) into three doses ( $1 / 3$ during land preparation, 1/3 15 days after transplanting and $1 / 360$ days after transplanting) was used under heat stress conditions.

The mean temperature $\left({ }^{\circ} \mathrm{C}\right)$ and relative air humidity (\%) within each month, averaged every 10 days are presented in Table (3).

Table (3): Maximum and minimum temperature $\left({ }^{\circ} \mathrm{C}\right)$ and relative humidity $(\%)$ at New Valley Agricultural Research Station averaged every 10 days during rice seasons 2015

\begin{tabular}{|c|l|l|l|l|}
\hline \multirow{2}{*}{ Month } & \multirow{2}{*}{ Date } & \multicolumn{3}{|c|}{ New Valley Governorate } \\
\cline { 3 - 5 } & & Average air Temp. 2015 & \multirow{2}{*}{ RH \% } \\
\cline { 2 - 5 } & & Max & Min & 26.0 \\
\hline \multirow{3}{*}{ May } & $\mathbf{1 - 1 0}$ & 36.2 & 21.1 & 25.0 \\
\cline { 2 - 5 } & $\mathbf{1 1 - 2 0}$ & 37.3 & 20.5 & 24.0 \\
\cline { 2 - 5 } & $\mathbf{2 1 - 3 1}$ & 40.3 & 23.8 & 22.0 \\
\hline \multirow{3}{*}{ June } & $\mathbf{1 - 1 0}$ & 39.9 & 25.8 & 26.0 \\
\cline { 2 - 5 } & $\mathbf{1 1 - 2 0}$ & 38.9 & 24.6 & 27.0 \\
\cline { 2 - 5 } & $\mathbf{2 1 - 3 0}$ & 38.7 & 23.5 & 28.0 \\
\hline \multirow{3}{*}{ July } & $\mathbf{1 - 1 0}$ & 38.5 & 23.7 & 27.0 \\
\cline { 2 - 5 } & $\mathbf{1 1 - 2 0}$ & 40.6 & 25.0 & 21.0 \\
\cline { 2 - 5 } & $\mathbf{2 1 - 3 1}$ & 43.2 & 29.1 & 22.0 \\
\hline \multirow{3}{*}{ August } & $\mathbf{1 - 1 0}$ & 45.2 & 26.4 & 30.9 \\
\cline { 2 - 5 } & $\mathbf{1 1 - 2 0}$ & 44.1 & 25.4 & 31.0 \\
\cline { 2 - 5 } & $\mathbf{2 1 - 3 1}$ & 39.9 & 25.8 & 31.0 \\
\hline \multirow{3}{*}{ September } & $\mathbf{1 - 1 0}$ & 40.5 & 25.8 & 27.0 \\
\cline { 2 - 5 } & $\mathbf{1 1 - 2 0}$ & 41.1 & & \\
\cline { 2 - 5 } & $\mathbf{2 1 - 3 0}$ & 41.5 & & \\
\hline
\end{tabular}

The characters measured on single plant basis included days to heading (day), plant height $(\mathrm{cm})$, pollen fertility (\%), total stigma length $(\mathrm{mm})$, anther length $(\mathrm{mm})$, number of panicles/ plant, sterility percentage (\%), 100-grain weight (g) and grain yield/ plant (g). All cultural practices were conducted during the growing season according to the recommended package of technology. Data on 90 randomly selected plants from each parent and $F_{1}$ generation, 150 plants from each back cross $\left(\mathrm{BC}_{1}\right.$ and $\left.\mathrm{BC}_{2}\right)$ and 300 plants from $F_{2}$ generation were recorded to determine the grain yield and the other studied characters. 


\section{Statistical and genetic analysis:}

The data under field condition of the present study were subjected to the proper statistical analysis of randomized complete block design, as described by Snedecor and Cochran (1967). Adequacy of scale must satisfy two conditions namely, additively of gene effects and independence of heritable component from nonheritable ones. The test of first condition provides information regarding absence or presence of gene interaction. The test of adequacy of scales is important because in most of the cases the estimation of additive and dominance components of variances were estimated assuming the absence of gene interaction. Mather (1949) and Hayman (1954) gave four tests for scale effects $A, B$ and $C$. The values of $A, B$ and $C$ should be equal to zero within the limit of their standard error. The significance of any one of these scales is taken to indicate the presence of non-allelic interaction. The scaling tests $A, B$ and $C$ were applied according to the formulae proposed by Mather (1949) and Hayman and Mather (1955) to test the presence of non-allelic interaction as following:

$$
\begin{aligned}
& A=2 \overline{B C}_{1}-\bar{P}_{1}-\bar{F}_{1} \\
& B=2 \overline{B C}_{2}-\bar{P}_{2}-\bar{F}_{1} \\
& C=4 \bar{F}_{2}-2 \bar{F}_{1}-\bar{P}_{1}-\bar{P}_{2} \text { and } \\
& V(A)=4 V\left(\overline{B C}_{1}\right)+V\left(\bar{P}_{1}\right)+V\left(\bar{F}_{1}\right) \\
& V(B)=4 V\left(\overline{B C}_{2}\right)+V\left(\bar{P}_{2}\right)+V\left(\bar{F}_{1}\right) \\
& V(C)=16 V\left(\bar{F}_{2}\right)+4 V\left(\bar{F}_{1}\right)+V\left(\bar{P}_{1}\right)+V\left(\bar{P}_{2}\right) \\
& S . E(A)=\sqrt{V A} \\
& \text { S.E }(B)=\sqrt{V B} \\
& \text { S.E }(C)=\sqrt{V C}
\end{aligned}
$$

Where,

$V A, V B$ and $V C$ are the variance of the different effects of $A, B$ and $C$, and $\mathrm{V}\left(\mathrm{P}_{1}\right), \mathrm{V}\left(\mathrm{P}_{2}\right), \mathrm{V}\left(\mathrm{F}_{1}\right), \mathrm{V}\left(\mathrm{BC}_{1}\right), \mathrm{V}\left(\mathrm{BC}_{2}\right)$ and $\mathrm{V}\left(\mathrm{F}_{2}\right)$ are the variance of mean of $P_{1}, P_{2}, F_{1}, B C_{1}, B C_{2}$ and $F_{2}$ populations respectively.

The "t" values are calculated as follows:

$$
\begin{aligned}
& t(A)=A / S . E(A) \\
& t(B)=B / S . E(B) \\
& t(C)=C / S . E(C)
\end{aligned}
$$


The calculated values of $(\mathrm{t})$ were compared with the tabulated value of $(\mathrm{t})$ at $5 \%$ and $1 \%$ level of significance. In each test, the degree of freedom are sum of the degrees of freedom of various generation involved.

According to the six parameters genetic model of Mather and Jinks (1982) as follows:

$m=$ Mean effects.

$d=$ Additive gene effects.

$\mathrm{h}=$ Dominance gene effects.

$\mathrm{i}=$ Additive $\mathrm{x}$ additive gene effects.

$\mathrm{j}=$ Additive $\mathrm{x}$ dominance gene effects.

$\mathrm{I}=$ Dominance $\mathrm{x}$ dominance gene effects.

The genetic parameters $\mathrm{m}, \mathrm{d}, \mathrm{h}, \mathrm{i}, \mathrm{j}$ and I were tested for significance using a t-test.

The amount of heterosis expressed in individual cross was determined by comparing the $F_{1}$ mean performance to the mid-parent and better-parent values and it was estimated by the formula of Mather (1949) and Mather and Jinks (1971). The relative potence ratio $(P)$ was used to determine the nature of dominance and its directions according to the formula given by Mather and Jinks (1971).

\section{Mean values.}

\section{RESULTS AND DISCUSSION}

The mean performance of the six populations $P_{1}, P_{2}, F_{1}, F_{2}$, $\mathrm{BC}_{1}$ and $\mathrm{BC}_{2}$ for the studied characters are presented in Table (4).

According to the data obtained from the three crosses under heat stress (Table 4), the $F_{1}$ (80.54 days) and $P_{1}$ headed after (77.13 days) and matured earlier than $\mathrm{P}_{2}$ (86.20 days) as well as segregating populations $\mathrm{F}_{2}$ (83.86 days), $\mathrm{BC} 1$ (81.32 days) and $\mathrm{BC}_{2}$ (82.37 days). The segregating population $\mathrm{BC}_{1}$ headed and matured earlier than the $F_{1}, F_{2}, P_{2}$ and $B C_{2}$. This result is desirable for the selection of early maturing plants in the future. The same trend was observed in the second and the third crosses.

Plant height, in $\mathrm{P}_{1}(68.14 \mathrm{~cm})$ was shorter than that of $\mathrm{P}_{2}$ $(113.28 \mathrm{~cm}), \mathrm{F}_{1}(87.20 \mathrm{~cm}), \mathrm{F}_{2}(101.21 \mathrm{~cm}), \mathrm{BC}_{1}(90.26 \mathrm{~cm})$ and $\mathrm{BC}_{2}$ $(102.69 \mathrm{~cm})$ in the first cross under heat stress conditions. The same trend was observed in the second and the third crosses.

Concerning pollen fertility (Table 4), the mean values in $\mathrm{P}_{2}$ $(57.57 \%)$ was slightly higher than $\mathrm{P}_{1}(14.50 \%), \mathrm{F}_{1}(32.63 \%), \mathrm{F}_{2}$ $(38.96 \%), \mathrm{BC}_{1}(34.07 \%)$ and $\mathrm{BC}_{2}(35.47 \%)$ under heat stress conditions in the cross No. 1. For the second and third crosses, pollen fertility $P_{2}$ values were higher than the other parent $\left(P_{1}\right)$ as well as the segregating populations $\left(F_{2}, B_{1}, B C_{2}\right.$ and $\left.F_{1}\right)$ except in the third cross 
$\mathrm{BC}_{1}(30.67)$ was higher than $\mathrm{P}_{1}(30.33 \%), \mathrm{P}_{2}(10.97 \%), \mathrm{F}_{1}(27.83 \%)$, $\mathrm{F}_{2}(25.36 \%)$ and $\mathrm{BC}_{2}(27.57 \%)$ under heat stress conditions.

Table (4): Mean performance of the studied traits in the three crosses under heat stress conditions

\begin{tabular}{|c|c|c|c|c|c|c|c|c|}
\hline Character & Cross & $\mathbf{P}_{1}$ & $\mathbf{P}_{2}$ & $F_{1}$ & $F_{2}$ & $\mathrm{BC}_{1}$ & $\mathrm{BC}_{2}$ & $\begin{array}{c}\text { LSD } \\
0.05 \pm 0.01\end{array}$ \\
\hline $\begin{array}{l}\text { Days to heading } \\
\text { (day) }\end{array}$ & $\begin{array}{l}\text { I } \\
\text { II } \\
\text { III }\end{array}$ & $\begin{array}{c}77.13 \pm 0.6 \\
78.41 \pm 0.43 \\
89.32 \pm 0.59\end{array}$ & $\begin{array}{l}86.20 \pm 0.60 \\
87.29 \pm 0.57 \\
97.11 \pm 0.47\end{array}$ & $\begin{array}{l}80.54 \pm 0.36 \\
79.80 \pm 0.41 \\
88.68 \pm 0.50\end{array}$ & $\begin{array}{l}83.86 \pm 0.65 \\
81.64 \pm 0.68 \\
89.34 \pm 0.89\end{array}$ & $\begin{array}{l}81.32 \pm 0.80 \\
81.09 \pm 0.81 \\
88.80 \pm 1.07\end{array}$ & $\begin{array}{l}82.37 \pm 0.84 \\
84.11 \pm 0.77 \\
91.46 \pm 1.13\end{array}$ & $\begin{array}{l}2.20 \pm 3.36 \\
3.54 \pm 5.40 \\
3.29 \pm 5.02\end{array}$ \\
\hline Plant height $(\mathrm{cm})$ & $\begin{array}{l}\text { I } \\
\text { II } \\
\text { III }\end{array}$ & $\begin{array}{l}68.14 \pm 0.25 \\
82.71 \pm 0.55 \\
69.63 \pm 0.50\end{array}$ & $\begin{array}{l}113.28 \pm 1.18 \\
\mathbf{1 1 3 . 4 7 \pm 0 . 5 1} \\
126.53 \pm 0.63\end{array}$ & $\begin{array}{l}87.20 \pm 0.28 \\
96.49 \pm 0.51 \\
111.87 \pm 0.80\end{array}$ & $\begin{array}{c}101.21 \pm 1.53 \\
\mathbf{1 0 5 . 9 1} \pm \mathbf{1 . 2 3} \\
108.63 \pm 1.34\end{array}$ & $\begin{array}{r}90.26 \pm 1.70 \\
98.10 \pm 1.48 \\
100.88 \pm 1.56\end{array}$ & $\begin{array}{r}102.69 \pm 1.56 \\
104.03 \pm 1.36 \\
111.55 \pm 1.46\end{array}$ & $\begin{array}{l}3.16 \pm 4.81 \\
2.25 \pm 3.43 \\
2.73 \pm 4.16\end{array}$ \\
\hline Pollen fertility (\%) & $\begin{array}{l}\text { I } \\
\text { II } \\
\text { III }\end{array}$ & $\begin{array}{l}14.50 \pm 1.12 \\
36.27 \pm 1.12 \\
30.33 \pm 1.24\end{array}$ & $\begin{array}{l}57.57 \pm 1.70 \\
79.93 \pm 1.53 \\
10.97 \pm 0.80\end{array}$ & $\begin{array}{l}32.63 \pm 1.62 \\
63.50 \pm 1.69 \\
27.83 \pm 1.51\end{array}$ & $\begin{array}{l}38.96 \pm 4.00 \\
59.89 \pm 4.23 \\
25.36 \pm 2.77\end{array}$ & $\begin{array}{l}34.07 \pm 4.48 \\
\mathbf{5 1 . 0 3} \pm 4.50 \\
30.67 \pm 3.21\end{array}$ & $\begin{array}{l}35.47 \pm 4.33 \\
\mathbf{5 2 . 5 0 \pm 4 . 5 1} \\
27.57 \pm 2.91\end{array}$ & $\begin{array}{c}6.43 \pm 9.81 \\
5.03 \pm 7.67 \\
8.34 \pm 12.72\end{array}$ \\
\hline $\begin{array}{l}\text { Total stigma length } \\
(\mathrm{mm})\end{array}$ & $\begin{array}{l}\text { I } \\
\text { II } \\
\text { III }\end{array}$ & $\begin{array}{l}1.04 \pm 0.01 \\
1.26 \pm 0.01 \\
1.03 \pm 0.02\end{array}$ & $\begin{array}{l}1.29 \pm 0.01 \\
1.32 \pm 0.01 \\
1.27 \pm 0.01\end{array}$ & $\begin{array}{l}1.11 \pm 0.01 \\
\mathbf{1 . 1 2} \pm 0.01 \\
1.23 \pm 0.01\end{array}$ & $\begin{array}{l}1.13 \pm 0.03 \\
1.22 \pm 0.03 \\
1.23 \pm 0.04\end{array}$ & $\begin{array}{l}1.07 \pm 0.04 \\
1.21 \pm 0.04 \\
1.11 \pm 0.05\end{array}$ & $\begin{array}{l}1.17 \pm 0.04 \\
1.22 \pm 0.05 \\
1.19 \pm 0.05\end{array}$ & $\begin{array}{l}0.04 \pm 0.06 \\
0.04 \pm 0.06 \\
0.03 \pm 0.05\end{array}$ \\
\hline Anther length $(\mathrm{mm})$ & $\begin{array}{l}\text { I } \\
\text { II } \\
\text { III }\end{array}$ & $\begin{array}{l}1.80 \pm 0.02 \\
1.82 \pm 0.02 \\
1.99 \pm 0.01\end{array}$ & $\begin{array}{l}2.28 \pm 0.02 \\
2.25 \pm 0.02 \\
1.98 \pm 0.02\end{array}$ & $\begin{array}{l}1.97 \pm 0.02 \\
\mathbf{2 . 0 2} \pm 0.02 \\
1.99 \pm 0.02\end{array}$ & $\begin{array}{l}1.88 \pm 0.04 \\
2.01 \pm 0.04 \\
2.06 \pm 0.03\end{array}$ & $\begin{array}{l}2.03 \pm 0.04 \\
2.00 \pm 0.05 \\
2.21 \pm 0.05\end{array}$ & $\begin{array}{l}2.09 \pm 0.06 \\
2.08 \pm 0.05 \\
2.24 \pm 0.05\end{array}$ & $\begin{array}{l}0.07 \pm 0.11 \\
0.08 \pm 0.12 \\
0.10 \pm 0.15\end{array}$ \\
\hline
\end{tabular}

\begin{tabular}{|c|c|c|c|c|c|c|c|c|}
\hline Character & Cross & $P_{1}$ & $\mathbf{P}_{2}$ & $F_{1}$ & $\mathbf{F}_{2}$ & $\mathrm{BC}_{1}$ & $\mathrm{BC}_{2}$ & $\begin{array}{c}\text { LSD } \\
0.05 \pm 0.01\end{array}$ \\
\hline $\begin{array}{c}\text { Number of panicles/ } \\
\text { plant }\end{array}$ & $\begin{array}{l}\text { I } \\
\text { II } \\
\text { III }\end{array}$ & $\begin{array}{c}13.20 \pm 0.29 \\
16.31 \pm 0.37 \\
14.47 \pm 0.35\end{array}$ & $\begin{array}{c}15.91 \pm 0.29 \\
17.13 \pm 0.39 \\
15.29 \pm 0.35\end{array}$ & $\begin{array}{l}15.95 \pm 0.34 \\
17.04 \pm 0.38 \\
15.00 \pm 0.33\end{array}$ & $\begin{array}{c}15.22 \pm 0.62 \\
17.70 \pm 0.75 \\
14.60 \pm 0.64\end{array}$ & $\begin{array}{c}14.33 \pm 0.81 \\
17.07 \pm 0.87 \\
13.93 \pm 0.81\end{array}$ & $\begin{array}{c}13.02 \pm 0.75 \\
15.82 \pm 0.91 \\
13.24 \pm 0.79\end{array}$ & $\begin{array}{l}1.07 \pm 1.63 \\
\mathbf{1 . 3 1} \pm 0.91 \\
1.99 \pm 1.39\end{array}$ \\
\hline $\begin{array}{c}\text { Sterility percentage } \\
\text { (\%) }\end{array}$ & $\begin{array}{l}\text { I } \\
\text { II } \\
\text { III }\end{array}$ & $\begin{array}{l}82.82 \pm 1.07 \\
\mathbf{5 1 . 1 0 \pm 1 . 6 2} \\
69.92 \pm 1.19\end{array}$ & $\begin{array}{l}67.50 \pm 0.98 \\
35.42 \pm 1.09 \\
85.78 \pm 0.64\end{array}$ & $\begin{array}{l}80.16 \pm 1.15 \\
33.26 \pm 0.95 \\
76.86 \pm 1.24\end{array}$ & $\begin{array}{l}72.30 \pm 2.72 \\
36.45 \pm 2.46 \\
71.40 \pm 2.86\end{array}$ & $\begin{array}{l}70.74 \pm 2.97 \\
36.95 \pm 2.88 \\
57.32 \pm 2.70\end{array}$ & $\begin{array}{l}74.85 \pm 2.72 \\
\mathbf{4 4 . 2 6} \pm 2.62 \\
69.32 \pm 3.22\end{array}$ & $\begin{array}{l}7.41 \pm 1.30 \\
3.43 \pm 5.24 \\
7.85 \pm 11.97\end{array}$ \\
\hline 100 -grain weight $(\mathrm{g})$ & $\begin{array}{l}\text { I } \\
\text { II } \\
\text { III }\end{array}$ & $\begin{array}{l}2.24 \pm 0.02 \\
2.25 \pm 0.02 \\
2.37 \pm 0.02\end{array}$ & $\begin{array}{l}2.79 \pm 0.02 \\
2.92 \pm 0.03 \\
2.86 \pm 0.02\end{array}$ & $\begin{array}{l}2.49 \pm 0.02 \\
2.68 \pm 0.03 \\
2.67 \pm 0.02\end{array}$ & $\begin{array}{l}2.40 \pm 0.06 \\
2.62 \pm 0.06 \\
2.57 \pm 0.05\end{array}$ & $\begin{array}{l}2.31 \pm 0.07 \\
2.69 \pm 0.07 \\
2.34 \pm 0.06\end{array}$ & $\begin{array}{l}2.56 \pm 0.08 \\
2.78 \pm 0.08 \\
2.61 \pm 0.08\end{array}$ & $\begin{array}{l}0.08 \pm 0.13 \\
0.13 \pm 0.20 \\
0.10 \pm 0.16\end{array}$ \\
\hline Grain yield/ Plant $(\mathrm{g})$ & $\begin{array}{l}\text { I } \\
\text { II } \\
\text { III }\end{array}$ & $\begin{array}{l}20.80 \pm 0.38 \\
22.47 \pm 0.36 \\
21.53 \pm 0.42\end{array}$ & $\begin{array}{l}24.21 \pm 0.44 \\
30.79 \pm 0.56 \\
23.61 \pm 0.63\end{array}$ & $\begin{array}{l}27.03 \pm 0.73 \\
34.66 \pm 0.67 \\
25.49 \pm 0.58\end{array}$ & $\begin{array}{l}26.99 \pm 0.83 \\
33.29 \pm 1.08 \\
24.62 \pm 0.89\end{array}$ & $\begin{array}{l}25.42 \pm 0.87 \\
\mathbf{3} 3.27 \pm \mathbf{1 . 1 2} \\
26.07 \pm 1.04\end{array}$ & $\begin{array}{l}26.64 \pm 1.00 \\
34.44 \pm 1.22 \\
24.14 \pm 0.93\end{array}$ & $\begin{array}{l}1.26 \pm 1.93 \\
\mathbf{2 . 8 5} \pm \mathbf{4 . 3 4} \\
1.29 \pm 1.97\end{array}$ \\
\hline
\end{tabular}

Crosses I: Sakha $105 \times$ WAB 880-1-32-1-2-P1-HB

Crosses II: Sakha $102 \times$ IRAT 170

Crosses III: Sakha $101 \times$ Moroberekan 
For the total stigma length, data in Table (4), indicated that the mean values in $P_{2}(1.29 \mathrm{~mm})$ was slightly higher than $P_{1}(1.04 \mathrm{~mm}), F_{1}$ $(1.11 \mathrm{~mm}), \mathrm{F}_{2}(1.13 \mathrm{~mm}), \mathrm{BC}_{1}(1.07 \mathrm{~mm})$ and $\mathrm{BC}_{2}(1.17 \mathrm{~mm})$ in the cross No. 1, and the same trend was observed in the second and third cross $P_{2}$ values were higher than the other parent $\left(P_{1}\right)$ as well as the segregating populations $\left(F_{2}, B_{1}, B C_{2}\right.$ and $\left.F_{1}\right)$ under heat stress conditions. With respect to the anther length, the mean values in $\mathrm{P}_{2}$ (2.28) was slightly higher than $P_{1}(1.80 \mathrm{~mm}), F_{1}(1.97 \mathrm{~mm}), F_{2}(1.88$ $\mathrm{mm}), \mathrm{BC}_{1}(2.03 \mathrm{~mm})$ and $\mathrm{BC}_{2}(2.09 \mathrm{~mm})$ in the three crosses studied under heat stress conditions. Concerning number of panicles/ plant (Table 4), the mean value in $F_{1}$ (15.95 panicles) was found to be higher than the parents $P_{1}$ (13.20 panicles) and $P_{2}$ (15.91 panicles) as well as the segregating populations in $\mathrm{F}_{2}$ (15.22 panicles), $\mathrm{BC}_{1}$ (14.33 panicles) and $\mathrm{BC}_{2}$ (13.02 panicles) in the cross No. 1, while $\mathrm{F}_{2}$ values in the second cross (17.70 panicles) was higher than $P_{1}$ (16.31 panicles), $\mathrm{P}_{2}$ (17.13 panicles), $\mathrm{F}_{1}$ (17.04 panicles), $\mathrm{BC}_{2}$ (17.07 panicles) and $\mathrm{BC}_{1}$ (15.82 panicles) under heat stress conditions. For the third crosses data revealed that, $\mathrm{P}_{2}$ value (15.29 panicles) was higher than $P_{1}$ (14.47 panicles), $F_{1}$ (15.00 panicles), $F_{2}$ (14.60 panicles), $\mathrm{BC}_{1}$ (13.93 panicles) and $\mathrm{BC}_{2}$ (13.24 panicles) under heat stress conditions.

The results in Table (4), showed that the sterility percentage in $\mathrm{P}_{1}(82.82 \%)$ was slightly higher than $\mathrm{P}_{2}(67.50 \%), \mathrm{F}_{1}(80.16 \%), \mathrm{F}_{2}$ $(72.30 \%), \mathrm{BC}_{1}(70.74 \%)$ and $\mathrm{BC}_{2}(74.85 \%)$ in the three crosses under heat stress conditions. Regarding 100-grain weight, the mean values in $P_{2}(2.79 \mathrm{~g})$ was higher than $P_{1}(2.24 \mathrm{~g}), F_{1}(2.49 \mathrm{~g}), F_{2}(2.40$ $\mathrm{g}), \mathrm{BC}_{1}(2.31 \mathrm{~g})$ and $\mathrm{BC}_{2}(2.56 \mathrm{~g})$ in the three crosses under heat stress conditions. With respect to grain yield per plant (Table 11), the mean values in $F_{1}(27.03 \mathrm{~g})$ was found to be higher than the parents $\mathrm{P}_{1}(20.80 \mathrm{~g})$ and $\mathrm{P}_{2}(24.21 \mathrm{~g})$ as well as the segregating populations in $\mathrm{F}_{2}(26.99 \mathrm{~g}), \mathrm{BC}_{1}(25.42 \mathrm{~g})$ and $\mathrm{BC}_{2}(26.64 \mathrm{~g})$ in the first and second cross except, the third crosses $\mathrm{BC}_{1}$ values $(26.07 \mathrm{~g})$ was higher than $P_{1}(21.53 \mathrm{~g}), \mathrm{P}_{2}(23.61 \mathrm{~g}), F_{1}(25.49 \mathrm{~g}), F_{2}(24.62 \mathrm{~g})$ and $\mathrm{BC}_{2}(24.14 \mathrm{~g})$ under heat stress conditions.

It could be concluded that, under heat stress conditions, the mean values of $\left(F_{1}\right.$ and $\left.B C_{1}\right)$ were the earlier in heading and the shortest in plant height in the three crosses. While, the mean values of $\left(F_{1}\right.$ and $\left.B_{2}\right)$ had the higher values of pollen fertility and anther length. The mean values of $\left(F_{1}\right.$ and $\left.F_{2}\right)$ have the higher values of No. of panicles/ plant in the three crosses. Meanwhile, the mean values of $\left(\mathrm{P}_{2}\right.$ and $\mathrm{BC}_{2}$ ) showed the higher values of 100 -grain weight. Concerning the mean values of grain yield/ plant the $\left(F_{1}\right)$ had the most desirable mean values under heat stress conditions. 


\section{Scaling test.}

Scaling test parameters (A, B, C) estimated for the studied characters in the three studied crosses under heat stress conditions are presented in Table (5).

Significant results of scaling test parameters indicate inadequacy of the additive- dominance model to interpret the gene effects involved in the materials. Epistatic contributions are important in the inheritance of these traits.

The estimated parameters of scaling test were significant for all the studied traits except for plant height in the third cross (cross III); and for number of panicles/ plant and grain yield/ plant in the first cross (cross I) under heat stress conditions. These results indicated that the six parameter model is valid to explain the nature of gene action for these characters.

While, A, B and C scaling tests were non- significant for the plant height, number of panicles/ plant and grain yield/ plant characters, the interaction model failed to explain the type of gene action.

Table (5): Scaling test A, B and C of the studied characters in the three tested crosses under heat stress conditions

\begin{tabular}{|c|c|c|c|c|}
\hline Character & Cross & $\mathbf{A}$ & B & $\mathbf{C}$ \\
\hline Days to heading (day) & $\begin{array}{l}\text { I } \\
\text { II } \\
\text { III }\end{array}$ & $\begin{array}{c}4.97 \pm 1.75^{\star} \\
3.97 \pm 1.72^{\star} \\
-0.40 \pm 2.27^{*}\end{array}$ & $\begin{array}{l}-2.01 \pm 1.83^{*} \\
1.13 \pm 1.70^{\star \star} \\
-2.88 \pm 2.37\end{array}$ & $\begin{array}{c}11.00 \pm 2.85 \\
1.26 \pm 2.94 \\
-6.43 \pm 3.76^{\star}\end{array}$ \\
\hline Plant height $(\mathrm{cm})$ & $\begin{array}{l}\text { I } \\
\text { II } \\
\text { III }\end{array}$ & $\begin{array}{l}25.17 \pm 3.42^{\star} \\
17.00 \pm 3.06^{\star} \\
20.27 \pm 3.25\end{array}$ & $\begin{array}{c}4.91 \pm 3.34 \\
-1.89 \pm 2.81 \\
-15.30 \pm 3.10\end{array}$ & $\begin{array}{l}49.00 \pm 6.26 \\
34.49 \pm 5.09 \\
14.61 \pm 5.64\end{array}$ \\
\hline Pollen fertility (\%) & $\begin{array}{l}\text { I } \\
\text { II } \\
\text { III }\end{array}$ & $\begin{array}{c}21.00 \pm 9.17^{* *} \\
2.30 \pm 9.22^{\star} \\
3.17 \pm 6.70^{*}\end{array}$ & $\begin{array}{c}-19.27 \pm 8.98 \\
-38.43 \pm 9.30^{*} \\
16.33 \pm 6.06^{*}\end{array}$ & $\begin{array}{l}18.49 \pm 16.45 \\
-3.64 \pm 17.38 \\
4.46 \pm 11.56^{* *}\end{array}$ \\
\hline Total stigma length (mm) & $\begin{array}{l}\text { I } \\
\text { II } \\
\text { III }\end{array}$ & $\begin{array}{l}-0.02 \pm 0.09^{\star} \\
\mathbf{0 . 0 4} \pm 0.08^{\star \star} \\
-0.05 \pm 0.09^{\star \star}\end{array}$ & $\begin{array}{c}-0.05 \pm 0.08^{* *} \\
\mathbf{0 . 0 0} \pm 0.10 \\
-0.12 \pm 0.09^{* *}\end{array}$ & $\begin{array}{l}-0.03 \pm 0.12^{\star} \\
0.06 \pm 0.14^{\star \star} \\
0.14 \pm 0.14^{\star \star}\end{array}$ \\
\hline Anther length $(\mathrm{mm})$ & $\begin{array}{l}\text { I } \\
\text { II } \\
\text { III }\end{array}$ & $\begin{array}{l}0.29 \pm 0.09^{\star \star} \\
0.16 \pm 0.10^{\star \star} \\
0.43 \pm 0.10^{\star \star}\end{array}$ & $\begin{array}{c}-0.07 \pm 0.12^{\star *} \\
-0.11 \pm 0.10^{\star \star} \\
0.53 \pm 0.10^{\star *}\end{array}$ & $\begin{array}{l}-0.50 \pm 0.16^{\star *} \\
-0.05 \pm 0.15^{\star} \\
0.31 \pm 0.14^{\star \star}\end{array}$ \\
\hline Number of panicles/ plant & $\begin{array}{l}\text { I } \\
\text { II } \\
\text { III }\end{array}$ & $\begin{array}{c}-0.04 \pm 1.68 \\
0.78 \pm 1.81^{\star} \\
-1.60 \pm 1.68^{\star \star}\end{array}$ & $\begin{array}{c}-5.38 \pm 1.57 \\
-2.53 \pm 1.89 \\
-3.80 \pm 1.65^{\star *}\end{array}$ & $\begin{array}{r}0.76 \pm 2.60 \\
3.27 \pm 3.15 \\
-1.36 \pm 2.69\end{array}$ \\
\hline Sterility percentage (\%) & $\begin{array}{l}\text { I } \\
\text { II } \\
\text { III }\end{array}$ & $\begin{array}{l}-21.50 \pm 6.14^{\star *} \\
-10.45 \pm 6.05^{\star *} \\
-32.13 \pm 5.67^{\text {**}}\end{array}$ & $\begin{array}{c}2.05 \pm 5.65 \\
19.85 \pm 5.44^{*} \\
-24.00 \pm 6.60^{* *}\end{array}$ & $\begin{array}{c}-21.43 \pm 11.22 * \\
-7.23 \pm 10.20 \\
-23.82 \pm 11.79\end{array}$ \\
\hline 100 -grain weight $(\mathrm{g})$ & $\begin{array}{l}\text { I } \\
\text { II } \\
\text { III }\end{array}$ & $\begin{array}{c}-0.11 \pm 0.14^{\star \star} \\
\mathbf{0 . 4 6} \pm 0.15^{\star \star} \\
-0.37 \pm 0.13^{\star \star}\end{array}$ & $\begin{array}{c}-0.17 \pm 0.17^{* *} \\
-0.03 \pm 0.16 \\
-0.30 \pm 0.16^{\star *}\end{array}$ & $\begin{array}{c}-0.41 \pm 0.23^{\star *} \\
-0.05 \pm 0.24 \\
-0.30 \pm 0.22^{\star *}\end{array}$ \\
\hline Grain yield/ Plant (g) & $\begin{array}{l}\text { I } \\
\text { II } \\
\text { III }\end{array}$ & $\begin{array}{c}5.68 \pm 1.84 \\
9.41 \pm 2.37^{\star \star} \\
5.13 \pm 2.21^{\star *}\end{array}$ & $\begin{array}{c}4.70 \pm 2.10 \\
3.43 \pm 2.60^{\star} \\
-0.81 \pm 2.04^{*}\end{array}$ & $\begin{array}{c}14.20 \pm 3.50 \\
10.57 \pm 4.57^{\star *} \\
2.37 \pm 3.82^{\star *}\end{array}$ \\
\hline
\end{tabular}

Note: * and ** Significant at 0.05 and 0.01 levels of probability, respectively.

Crosses I: Sakha $105 \times$ WAB 880-1-32-1-2-P1-HB

Crosses II: Sakha $102 \times$ IRAT 170

Crosses III: Sakha $101 \times$ Moroberekan 


\section{Type of gene action}

The additive gene effects (d), were negative and significant (Table 6), for days to heading and grain yield/ plant in cross No. 2, for plant height in all studied crosses, for sterility percentage in cross No. 3 and for 100-grain weight in cross No. 1 and cross No. 3. These results indicated that the materials in the crosses have decreasing alleles for these characters and selection to improve it could be effective except for days to heading and plant height if it earlier and shorter plants are desired. The results are in agreement with those reported by Sharifi (2008), AbdAllah et al. (2010) and Yadav et al. (2010).

The dominance gene effects (h) as shown in Table (6), were positive and significant for anther length in cross No. 1 and cross No. 3 . This indicating the presence of dominance gene effects in the inheritance of this character, except days to heading in cross No. 1, plant height in cross No. 1 and cross No. 2 and sterility percentage in cross No. 3 were found to be negative and significant. The results obtained indicated that the alleles responsible for less values of these mentioned traits were dominant over the alleles governing the high values.

On the other hand, the additive by additive (i), type of gene action were found to have negative and significant effects for days to heading in cross No. 1, for plant height in cross No. 1 and cross No. 2, and for sterility percentage in cross No. 3. This indicating that effective selection for these characters could be achieved in the late generations. With respect to additive by dominance (j), type of gene action (Table 6), positive and significant effects were detected for days to heading, anther length and number of panicles/ plant in cross No. 1, for plant height in the three crosses studied, for pollen fertility in cross No. 1 and cross No. 2, for 100-grain weight in cross No. 2 and for grain yield/ plant in cross No. 3. Negative and significant effects of additive $x$ dominance type of gene (j), were detected for sterility percentage in cross No. 3 , the negative of interaction suggested dispersion of genes in the parents. With regard to dominance $x$ dominance type of gene effects (I), positive and significant and highly significant effects were obtained for pollen fertility in cross No. 2, for number of panicles/ plant in cross No. 3, and for sterility percentage and grain yield/ plant in cross No. 3. These results indicated that the role of dominance by dominance gene interaction are important in the inheritance of these characters. Negative and significant effects of dominance $x$ dominance type of gene effects (I) were detected for anther length in cross No. 1 and cross No. 3 under heat stress conditions. These results indicated that the scope of heterosis breeding for the development of superior populations. 
Table (6) Estimation of gene effects based on six generation means for the studied characters under heat stress conditions

\begin{tabular}{|c|c|c|c|c|c|c|c|}
\hline Character & Cross & $F_{2}$ deviation & d & h & $\mathbf{i}$ & j & I \\
\hline Plant height $(\mathrm{cm})$ & $\begin{array}{l}\text { I } \\
\text { II } \\
\text { III }\end{array}$ & $\begin{array}{c}101.21^{* *} \\
105.91^{\star *} \\
108.63^{\star *}\end{array}$ & $\begin{array}{c}-12.43^{\star \star} \\
-5.93^{\star \star} \\
-10.67^{\star *}\end{array}$ & $\begin{array}{c}-22.43^{\star *} \\
-20.98^{\star *} \\
4.14\end{array}$ & $\begin{array}{c}-18.92^{*} \\
-19.38^{\star \star} \\
-9.64\end{array}$ & $\begin{array}{c}10.13^{\star *} \\
9.44^{\star \star} \\
17.78^{\star *}\end{array}$ & $\begin{array}{c}-11.16 \\
4.27 \\
4.68\end{array}$ \\
\hline Pollen fertility (\%) & $\begin{array}{l}\text { I } \\
\text { II } \\
\text { III }\end{array}$ & $\begin{array}{l}38.96^{\star *} \\
59.89^{\star \star} \\
25.36^{\star *}\end{array}$ & $\begin{array}{c}-1.40 \\
-1.47 \\
3.10\end{array}$ & $\begin{array}{r}-20.16 \\
-27.09 \\
22.23\end{array}$ & $\begin{array}{c}-16.76 \\
-32.49 \\
15.04\end{array}$ & $\begin{array}{c}20.13^{\star \star} \\
20.37^{\star \star} \\
-6.58\end{array}$ & $\begin{array}{c}15.02 \\
68.62^{\star} \\
-34.54\end{array}$ \\
\hline $\begin{array}{l}\text { Total stigma } \\
\text { length }(\mathrm{mm})\end{array}$ & $\begin{array}{l}\text { I } \\
\text { II } \\
\text { III }\end{array}$ & $\begin{array}{l}1.13^{\star *} \\
1.22^{\star *} \\
1.23^{\star *}\end{array}$ & $\begin{array}{l}-0.11 \\
-0.01 \\
-0.09\end{array}$ & $\begin{array}{l}-0.09 \\
-0.19 \\
-0.23\end{array}$ & $\begin{array}{l}-0.04 \\
-0.02 \\
-0.31\end{array}$ & $\begin{array}{l}0.02 \\
0.02 \\
0.03\end{array}$ & $\begin{array}{c}0.11 \\
-0.02 \\
0.49\end{array}$ \\
\hline $\begin{array}{c}\text { Number of } \\
\text { panicles/ plant }\end{array}$ & $\begin{array}{l}\text { I } \\
\text { II } \\
\text { III }\end{array}$ & $\begin{array}{l}15.22^{\star *} \\
17.70^{\star \star} \\
14.60^{\star *}\end{array}$ & $\begin{array}{l}1.31 \\
1.24 \\
0.69\end{array}$ & $\begin{array}{l}-5.22 \\
-4.70 \\
-3.92\end{array}$ & $\begin{array}{l}-6.18 \\
-5.02 \\
-4.04\end{array}$ & $\begin{array}{l}2.67^{*} \\
1.66 \\
1.10\end{array}$ & $\begin{array}{c}11.60^{*} \\
6.78 \\
9.44\end{array}$ \\
\hline $\begin{array}{c}\text { Sterility } \\
\text { percentage (\%) }\end{array}$ & $\begin{array}{l}\text { I } \\
\text { II } \\
\text { III }\end{array}$ & $\begin{array}{l}72.30^{\star *} \\
36.45^{\star \star} \\
71.40^{\star *}\end{array}$ & $\begin{array}{c}-4.11 \\
-7.31 \\
-12.00^{* *}\end{array}$ & $\begin{array}{c}6.97 \\
6.63 \\
-33.31^{*}\end{array}$ & $\begin{array}{c}1.98 \\
16.63 \\
-32.31^{*}\end{array}$ & $\begin{array}{c}-11.77^{\star \star} \\
-15.15^{\star \star} \\
-4.07\end{array}$ & $\begin{array}{r}17.48 \\
-26.03 \\
88.44^{* *}\end{array}$ \\
\hline $\begin{array}{c}\text { 100-grain weight } \\
(\mathrm{g})\end{array}$ & $\begin{array}{l}\text { I } \\
\text { II } \\
\text { III }\end{array}$ & $\begin{array}{l}2.40^{\star *} \\
2.62^{\star \star} \\
2.57^{\star *}\end{array}$ & $\begin{array}{c}-0.25^{\star} \\
-0.09 \\
-0.28^{\star *}\end{array}$ & $\begin{array}{c}0.10 \\
0.57 \\
-0.32\end{array}$ & $\begin{array}{c}0.13 \\
\mathbf{0 . 4 8} \\
-0.37\end{array}$ & $\begin{array}{c}0.03 \\
0.24^{\star} \\
-0.03\end{array}$ & $\begin{array}{c}0.14 \\
-0.92 \\
1.05^{\star}\end{array}$ \\
\hline
\end{tabular}

Note: ${ }^{*}$ and ${ }^{* *}$ Significant at 0.05 and 0.01 levels of probability, respectively.

Crosses I: Sakha $105 \times$ WAB 880-1-32-1-2-P1-HB Crosses III: Sakha $101 \times$ Moroberekan

Crosses II: Sakha $102 \times$ IRAT 170

$\mathrm{d}=$ Additive gene effects.

$\mathrm{h}=$ Dominance gene effects.

$\mathrm{i}=$ Additive $\mathrm{x}$ additive gene effects.

$\mathrm{j}=$ Additive $\mathrm{x}$ dominance gene effects.

$\mathrm{I}=$ Dominance $\mathrm{x}$ dominance gene effects.

\section{Estimates of heterosis and potence ratio.}

Data presented in Table (7), showed heterotic effect calculated as percentage over mid-parent and better-parent and potence ratio for the studied traits in the three crosses.

Significant positive heterosis relative to mid-parents in the cross No. 3 was recorded for plant height $(14.05 \%)$, pollen fertility (34.79\%) and total stigma length $(7.03 \%)$, for number of panicles/ plant $(6.56 \%)$ in the cross No. 1, for 100-grain weight (3.51 and 2.02 $\%)$ in the cross No.2 and cross No. 3, respectively and for grain yield/ plant $(8.26,30.16$ and $12.93 \%)$ in the three crosses. These results indicated that dominance direction was toward the best respective parent, the significant heterotic effect might be due to the dominance 
or dominance $x$ dominance effects. These results agreed with those obtained by Abdelkhalik et al. (2010).

Table (7): Percentage of heterosis over mid-parent (MP) and better-parent (BP) and potence ratio for the studied characters of the three crosses under heat stress conditions

\begin{tabular}{|c|c|c|c|c|}
\hline Character & Cross & & & Potence ratio (\%) \\
\hline Days to heading (day) & $\begin{array}{l}\text { I } \\
\text { II } \\
\text { III }\end{array}$ & $\begin{array}{l}-1.37 \\
-3.68 \\
-4.87\end{array}$ & $\begin{array}{c}4.42 \\
1.77^{\star \star} \\
-0.72^{\star \star}\end{array}$ & $\begin{array}{l}-0.25 \\
-0.69 \\
-1.17\end{array}$ \\
\hline Plant height $(\mathrm{cm})$ & $\begin{array}{l}\text { I } \\
\text { II } \\
\text { III }\end{array}$ & $\begin{array}{c}-3.87 \\
-1.63 \\
14.05^{\star \star}\end{array}$ & $\begin{array}{l}27.96^{* *} \\
16.66^{\star \star} \\
60.65^{\star \star}\end{array}$ & $\begin{array}{l}-0.16 \\
-0.10 \\
0.48\end{array}$ \\
\hline Pollen fertility (\%) & $\begin{array}{l}\text { I } \\
\text { II } \\
\text { III }\end{array}$ & $\begin{array}{c}-9.44 \\
9.29 \\
34.79^{* *}\end{array}$ & $\begin{array}{c}-43.31^{\star *} \\
-20.56^{\star \star} \\
-8.24^{* \star}\end{array}$ & $\begin{array}{c}-0.16 \\
\mathbf{0 . 2 5} \\
-0.74\end{array}$ \\
\hline Total stigma length $(\mathrm{mm})$ & $\begin{array}{l}\text { I } \\
\text { II } \\
\text { III }\end{array}$ & $\begin{array}{c}-4.31^{\star *} \\
-13.39^{\star *} \\
7.03^{\star *}\end{array}$ & $\begin{array}{c}-13.58^{\star \star} \\
-15.42^{\star \star} \\
-3.19^{\star \star}\end{array}$ & $\begin{array}{l}-0.40 \\
-5.58 \\
0.67\end{array}$ \\
\hline Anther length (mm) & $\begin{array}{l}\text { I } \\
\text { II } \\
\text { III }\end{array}$ & $\begin{array}{c}-3.35^{\star \star} \\
-0.44^{\star \star} \\
0.20\end{array}$ & $\begin{array}{c}-13.44^{\star \star} \\
-10.00^{\star \star} \\
-0.13^{\star \star}\end{array}$ & $\begin{array}{l}-0.29 \\
-0.04 \\
-0.60\end{array}$ \\
\hline Number of panicles/plant & $\begin{array}{l}\text { I } \\
\text { II } \\
\text { III }\end{array}$ & $\begin{array}{c}6.56^{* \star} \\
1.93 \\
0.82\end{array}$ & $\begin{array}{c}-2.51^{\star *} \\
-0.52 \\
-1.89^{\star \star}\end{array}$ & $\begin{array}{l}0.70 \\
0.78 \\
0.30\end{array}$ \\
\hline Sterility percentage (\%) & $\begin{array}{l}\text { I } \\
\text { II } \\
\text { III }\end{array}$ & $\begin{array}{c}6.65 \\
-\mathbf{2 3 . 1 2 ^ { \star \star }} \\
-1.28\end{array}$ & $\begin{array}{l}18.75^{\star \star} \\
-6.10^{\star \star} \\
9.92^{\star \star}\end{array}$ & $\begin{array}{l}-0.65 \\
1.28 \\
-0.13\end{array}$ \\
\hline 100-grain weight (g) & $\begin{array}{l}\text { I } \\
\text { II } \\
\text { III }\end{array}$ & $\begin{array}{l}-1.22^{\star \star} \\
3.51^{\star \star} \\
2.02^{\star \star}\end{array}$ & $\begin{array}{c}-11.00^{\star *} \\
-8.37^{\star \star} \\
-6.58^{\star \star}\end{array}$ & $\begin{array}{l}-0.11 \\
\mathbf{0 . 2 7} \\
0.22\end{array}$ \\
\hline Grain yield/ Plant (g) & $\begin{array}{l}\text { I } \\
\text { II } \\
\text { III }\end{array}$ & $\begin{array}{c}8.26^{* \star} \\
30.16^{\star \star} \\
12.93^{\star *}\end{array}$ & $\begin{array}{c}0.63 \\
12.59 \\
7.94\end{array}$ & $\begin{array}{l}1.09 \\
1.93 \\
2.80\end{array}$ \\
\hline
\end{tabular}

Note: ${ }^{*}$ and ${ }^{* *}$ Significant at 0.05 and 0.01 levels of probability, respectively.

Crosses I: Sakha $105 \times$ WAB 880-1-32-1-2-P1-HB

Crosses II: Sakha $102 \times$ IRAT 170

Crosses III: Sakha $101 \times$ Moroberekan

On the other hand, negative percentage over the better parents in Table (7), obtained for pollen fertility, total stigma length, anther length and 100-grain weight in the three crosses studied. While, significant negative heterotic effect was found for days to heading in cross No 3 , for number of panicles/ plant in cross No 2 and cross No 3 and for sterility percentage in cross No 2 . This cross could be used in rice breeding program for improving these traits, where negative values of heterosis would be of interest in some traits such as days to heading, pollen fertility, total stigma length, anther length, number of panicles/ plant and 100-grain weight.

\section{Potence ratio:}

The data of potence ratio are presented in Table (7), the values were more than one for grain yield/ plant (1.09, 1.93 and 2.80) in the three cross studied, respectively and for total stigma length and sterility percentage (5.58 and 1.28 ), respectively in cross No. 2, 
indicating the presence of over dominance for these characters in the three crosses under heat stress conditions.

The values of potence ratio were less than one for days to heading, plant height, pollen fertility, anther length, number of panicles/ plant and 100-grain weight in the three crosses, and for total stigma length and sterility percentage in the cross No. 1 and cross No. 3 under heat stresses conditions, indicating the presence of partial dominance for these traits.

From the previous results, it could be indicated that, the most desirable cross was cross No.1 for anther length, number of panicles/ plant, sterility percentage and grain yield/ plant; cross No. 2 for days to heading, plant height, pollen fertility, anther length, number of panicles/ plant, 100-grain weight and grain yield/ plant; cross No. 3 for pollen fertility, sterility percentage and grain yield/ plant.

\section{REFERENCES}

AbdAllah, A.A.; W.M. El Khoby; M. Aboyosif and R.N. Gorgy. (2010). Phenotypic and genotypic analysis of some rice varieties for growth and yield traits under stress conditions. J. Plant Prod. Mansoura Univ., 1(7): 901-914.

Abdelkhalik A.F.; E.M.R. Metwali; M. El-Ali; A.H. Abd El-Hadi and D.E. ElSharnobi. (2010). Genotypes $x$ environment interactions for seedling vigor traits in rice (Oryza sativa, L.) genotypes grown under low and high temperature conditions. Am-Euras. J. Agric. \& Environ. Sci., 8(3): 257-267.

Hayman, B.I. (1954). The theory and analysis of diallel crosses. Genetics, 39: 789-809.

Hayman, B.I. and K. Mather. (1955). The description of genetic interaction in continuous variation. Biometrics, 11: 69-82.

Mather, K. (1949). Biometrical Genetic. Dover Publication, inc. London.

Mather, K. and J.L. Jinks. (1971). Biometrical genetics. $2^{\text {nd }}$ Ed. Chammpan and Hall Ltd., London, pp. 382.

Mather, K. and J.L. Jinks. (1982). Biometrical genetics. $3^{\text {rd }}$ Ed. Cambridge Univ. press, London, pp. 396.

Peng, S.; J. Huang; J.E. Sheehy; R.C. Laza; R.M. Visperas; X. Zhong; C.S. Centeno; G.S. Khush and K.G. Cassman. (2004). Rice yields decline with higher night temperature from global warming. Proc. Natl. Acad. Sci. USA 101(27): 9971-9975.

Sharifi, P. (2008). Inheritance of cold tolerance in rice at the germination stage. Asian J. Plant Sci., 1-5.

Snedecor, G.W. and Cochran. (1967). Statistical Methods $6^{\text {th }}$ Ed. lowa State University Press, Amer, lowa, USA.

Tester, M. and M. Bacic. (2005). Abiotic stress tolerance in grasses. From Model Plants to Crop Plants. Plant Physiology, 137(3): 791793. 
Yadav, P.; N.R. Rangare; P.J. Anurag and A.K. Chaurasia. (2010). Quantitative analysis of rice (Oryza sativa, L.) in Allahabad agro climate zone. J. of Rice Research, 3(1): 16-18.

Zou, J.; C. Liu and X. Chen. (2011). Proteomics of rice in response to heat stress and advances in genetic engineering for heat tolerance in rice. Plant Cell Rep., 30:2155-2165.

$$
\text { وراثة تحمل الحرارة العالية والصفات المرتبطة بها في الارز }
$$

عبدالعزيز جلال عبدالحافظ 1، عبدالله عبدالنبي عبداللهّ2 ، إبراهيم سعد الدجوي1 و محمد إبرا هيم غُازي 2

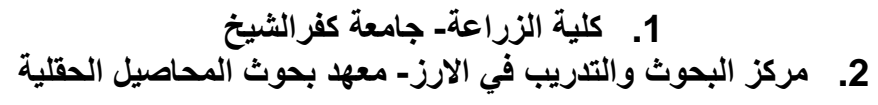

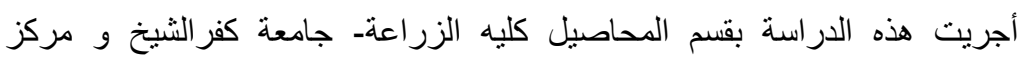

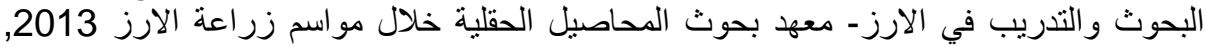

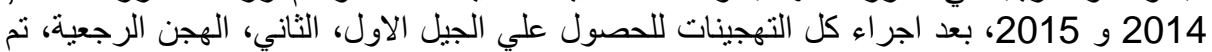

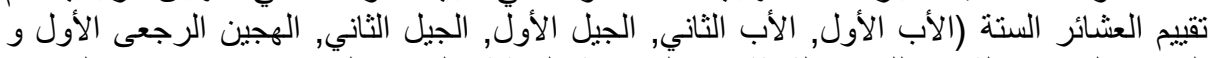

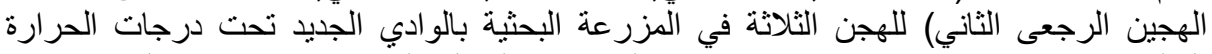

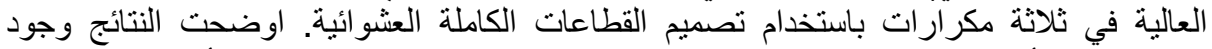

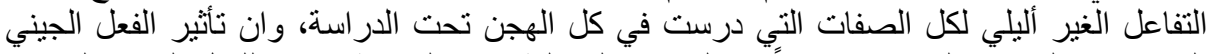

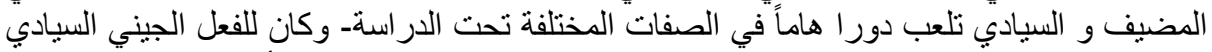

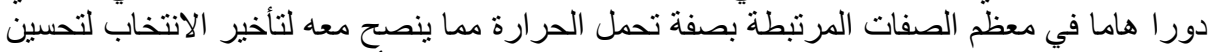

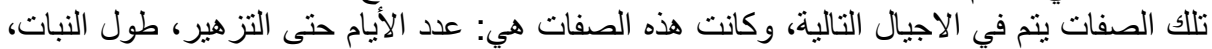

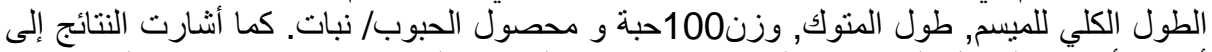

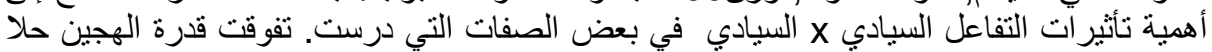

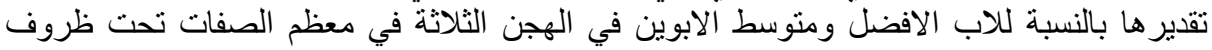

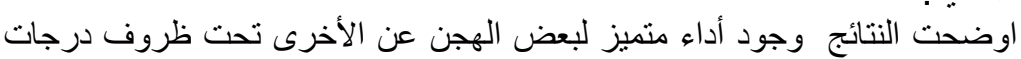

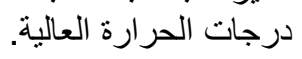

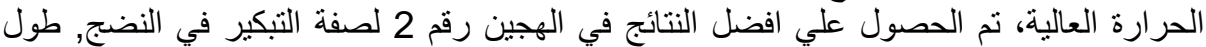

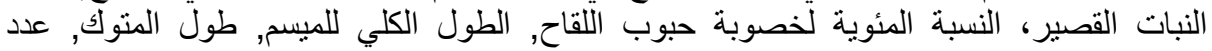

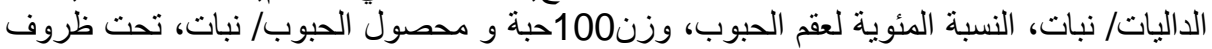

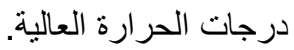

